\title{
A VÁROSI NÉPESSÉG TÉRSZERKEZETE EURÓPA POSZT-SZOCIALISTA RÉGIÓJÁBAN ${ }^{1}$
}

\author{
(Development of Social-demographic Intraurban Structure of \\ the City in the Post-socialist Region of Europe)
}

\author{
JANETTA DICKÁ
}

\begin{abstract}
Kulcsszavak:
városszociológia térszerkezet posztkommunista országok

A posztkommunista országok városainak belsö térszerkezete eltérổ módon változott az elmúlt évtizedekben. A marxista városfejlesztés Szovjetünióban kidolgozott mintảja alapjản az ipar igényei és a tảrsadalmi egyenlosség megteremtése céljából formálták a városokat. Az egyenlóség ideológiája a városok közti különbségek kialakulását is ellenezte. A kommunista diktatúrák bukásával a piaci viszonyok, a magántulajdon megerösödése és a politikai pluralizmus lett a fö alakitója a városok belsö térszerkezetének. Az épittett környezet sajátossága miatt az átalakulás lassú folyamat, de már láthatóak az eredmények. A belvárosok új funkciót kaptak, a népesség elkülönülése jövedelmi szinvonaluk alapján felerősödött. A városok közti verseny miatt jelentös különbségek kezdenek mutatkozni mind az épitett környezetben, mind a lakosok életkörülményeiben.
\end{abstract}

\section{Bevezetés}

Egy település, azon belül a városi települések fejlödését nem pusztán a földrajzi elhelyezkedés befolyásolja. Közvetlen hatással van rá lakosságának összetétele is. Fontos szerepet játszik a város országon belüli földrajzi elhelyezkedése, az általa gyakorolt funkciók, valamint politikai és gazdasági szerepköre is. Az 1989 után bekövetkezett politikai és társadalmi változások, amelyek Közép- és Kelet-Európa államait érték, nagy hatással voltak az átmenet időszakában a városok népességének településen belüli elhelyezkedésére, azaz a népesség városi térszerkezetére is.

A tanulmány célja, hogy bemutassa a városi lakóhelyek térszerkezetének változását a városok fejlődésének emlitett két idószakában.

\section{A szocialista város}

A városok kitüntetett helyzete és a városokat ért jelentős változások KözépEurópában igénylik, hogy vizsgáljuk társadalmuk és népesedésük változását a létezỏ szocializmus időszakában és az azt követő átmeneti időszakban.

A szocialista rendszer a városok fejlödését a második világháborútól kezdve a nyolcvanas évek végéig befolyásolta, azaz 45 éven át tartó befolyást és hatást kell vizsgálnunk. Kevés tanulmány vállalkozott arra, hogy a szocialista vagy kommunista városok jellemzỏit megfogalmazza. Ezek közül meghatározó jelentőségü Hamilton A szocialista város címủ munkája. Sok szerző hivatkozik alapos megfi- 
gyeléseire, amikor a szocialista város vagy a szocialista városodás jelenségéről szól (pl. Enyedi).

A szocialista város területi szerkezete az iparosítás és a modernizálás ủtjản valósult meg és ezeken a folyamatokon keresztül vezérelték központilag a társadalom tervezését. Mindezek miatt sok szerző (Musil 2002; Matlovič 2004) a szocialista városiasodás folyamatát az általános városodási folyamatok különös változatának tekintette, amely a központi tervezésben gyökerezett. A központi tervezés elhanyagolta a városok helyzeti előnyeit, aminek következtében a legnagyobb városok növekedése lelassult. A létező szocializmus városkoncepciója tulajdonképpen az 1920-as években formálódott a Szovjetunióban. Ideológiai hátterét a marxizmus szolgáltatta. Friedrich Engels szerint a fö lépések közé tartozik a piaci mechanizmusok fölszámolása, a városi és falusi területek közti különbségek lebontása, az ipar és a népesség kiegyensúlyozott elhelyezése, valamint az ipari és a mezögazdasági területek szisztematikus területi egyesítése (Matlovič 2004). A szocialista város (azaz a kommunista és szocialista állam befolyása alatt növekvő városok) fejlỏdésének alapvetô célja volt a társadalmi egyenlőség és a polgári osztály felszámolása (French-Hamilton 1979 - idézi Rouppila 2004). Abból a célból, hogy osztály nélküli és kulturális különbségek nélküli városokat hozzanak létre, a városépítés folyamatának alapjává a szocialista társadalom alapját, a munkásosztályt tették. Ennek ellenére a kutatások bebizonyították, hogy a szocialista városokban gazdasági és társadalmi szempontokat nézve megmaradtak a társadalmi csoportok között a területi különbségek. A városi egyenlőtlenségek megléte érvényes mind a polgári múlttal rendelkező városokra, mind a tipikusan szocialista városokra. Smith (1996) szerint a társadalmi egyenlötlenségek mértéke a szocializmus idején kisebb volt, mint a kapitalizmusban. A lakókörülmények közti különbség fellelhető volt a magas társadalmi státusszal rendelkező lakók csoportja és a többi városlakó között. A szocialista városok térszerkezeti mintázata nem követte a klasszikus területi modelleket (körkörös, sávos-szakaszos, többközpontú stb.), viszont a klasszikus térszerkezeti modellek minden eleme felfedezhető bennük (Rouppila 2004).

A fenti okokból a szocialista korszakból megmaradt a városok társadalmára jellemző néhány térszerkezeti sajátosság. Ezek alapján Matlovič (2004) megfogalmazta a szocialista város jellemzőit ( 1 . táblázat), melyek érvényesek mind az egész városra, de annak egyes részeire is, kerületi egységet értve ez alatt. Ezek a városok, illetve ezek a kerületek a szocializmus időszaka alatt formálódtak a korra jellemző elvek alapján. Amennyiben térszerkezetük a szocializmus alatt módosult, az a szocialista városítás elvei alapján történt. Ebben a tekintetben a szocialista városnak több típusát tudjuk meghatározni:

1) a teljesen szocialista városok: ilyenek az új alapítású városok, mint Nová Dubnica, vagy egy környékbeli „bolygó” település egybeolvasztása a szomszédos várossal, mint Nowa Huta csatolása Krakkóhoz, Poruba csatolása Ostravához, Saca egyesítése Kassával; 
Janetta Dická : A városi népesség térszerkezete Európa poszt-szocialista régiójában.

Tér és Társadalom 21. évf. 2007/3. 187-195. p.

TÉT XXI. évf. 2007 a 3

Kitekintö

189

\begin{tabular}{|c|c|}
\hline & $\begin{array}{c}\text { 1. TÁBLÁZAT } \\
\text { A szocialista városok elsödleges jellemzôi } \\
\text { (Primary Features of the Socialist City) }\end{array}$ \\
\hline $\begin{array}{l}\text { Általános } \\
\text { jellemzők }\end{array}$ & $\begin{array}{l}\text { - A piac hiánya és a földjáradék durva mellözése; } \\
\text { - a tulajdon államosítása; } \\
\text { - az irányítás központi-bürokratikus rendszere, a helyi önkormányzás } \\
\text { fölszámolása, a helyi igazgatás függése a központi kormányzattól; } \\
\text { - a kommunista párt hatalmi-politikai monopóliuma; } \\
\text { - ideológiai és politikai ismérvek elsőbbsége a gazdasági érdekek- } \\
\text { kel szemben a települések benépesítésében és a társadalmi- } \\
\text { gazdasági cselekvésekben, melyek célja a városi egyenlőség } \\
\text { megteremtése volt társadalmi és területi különbségek nélkül; } \\
\text { - a lakókörülmények, az esztétikai szempontok alábecslése; } \\
\text { - egyenlősitỏ belpolitika; } \\
\text { - a normativitás és a hasznosság elvének alkalmazása a területi } \\
\text { tervezésben; } \\
\text { - a nehézipar elönyben részesitése a városok iparositása alkalmával; } \\
\text { - a lakóépületek technológiai és ipari irányultságú fejlesztése, a töme- } \\
\text { ges építésre helyezve a hangsúlyt, és az egyes elemektől kezdve a } \\
\text { teljes építményig törekedve a sorozatgyártásra, a típusalakitásra, az } \\
\text { állandó szerkezeti formákra; } \\
\text { - a falusiak tömeges beköltözése a városokba; } \\
\text { - a környezeti gondok lebecsülése. }\end{array}$ \\
\hline $\begin{array}{l}\text { A városok } \\
\text { épitészeti } \\
\text { jellemzói }\end{array}$ & $\begin{array}{l}\text { - A belvárosok elhanyagolása; } \\
\text { - nagyszámú használaton kívüli értékes földterület a város belsô ré- } \\
\text { szein (kedvező fekvés, müszaki infrastruktúrával való ellátottság); } \\
\text { - monoton felépítésủ és kinézetü tömbházak építése túltengő } \\
\text { mennyiségben; } \\
\text { - az épületek dekorativitására figyelö rövid periódus után a modern } \\
\text { városépítészet vulgarizált változatának elterjedése a változatos- } \\
\text { ság mérhetetlenül alacsony szintjével. }\end{array}$ \\
\hline $\begin{array}{l}\text { A városok } \\
\text { funkcionális } \\
\text { jellemzői }\end{array}$ & $\begin{array}{l}\text { - Tömbházak építésének elsőbbsége; } \\
\text { - az egyedi lakások építésének visszaesése; } \\
\text { - a célnak megfelelö szerkezetek eröteljes fejlesztése; } \\
\text { - az ipari területek fejlesztése. }\end{array}$ \\
\hline $\begin{array}{l}\text { A társadalom } \\
\text { térszerkezete }\end{array}$ & $\begin{array}{l}\text { - Egységesítő törekvések a városi terek társadalmi-gazdasági } \\
\text { különbségeinek felszámolására; } \\
\text { - a lakosok társadalmi-gazdasági helyzetük alapján kevert és véletlen } \\
\text { csoportjainak együttléte és rendkívuil kis mértékü szegregáció; } \\
\text { - a város térszerkezetében fellelhetô társadalmi különbségek a } \\
\text { lakások adminisztratív (állami) elosztásának a következménye; } \\
\text { - a lakótelepi népességre két generáció együttélése jellemző; } \\
\text { - a belváros éles területi kủlönbségei a családok helyzetével (státu- } \\
\text { szával) függenek össze; } \\
\text { - a belváros elfalusiasodása a falusi lakosok beköltözésének követ- } \\
\text { kezménye; } \\
\text { - a népesség marginális csoportjai alacsony arányban vannak jelen. }\end{array}$ \\
\hline
\end{tabular}

Forrás: Matlovič (2004). 
Janetta Dická : A városi népesség térszerkezete Európa poszt-szocialista régiójában.

Tér és Társadalom 21. évf. 2007/3. 187-195. p.

2) a beköltöztetések útján szocialistává formált városok: eredetileg kis- és középvárosokról van szó, amelyek a szocialista iparosítás következtében rohamosan fejlödésnek indultak (ilyen volt Vágbeszterce, Garamszentkereszt);

3) városok markáns szocialista munkástelepekkel és megmaradt „preszocialista maggal", hagyományos belvárosi maggal: ezekben a városokban jelentős fejlődés ment végbe a szocializmus alatt, szocialista kerületek gyürüje veszi körül a régi lakótömböket (Pozsony, Kassa, Eperjes, Budapest, Lodz, Lublin);

4) városok a szocialista urbanizáció lanyha jeleivel: ezek a városok gazdasági és demográfiai értelemben stagnáltak a szocializmus évei alatt (ilyen volt Fejérkő, Lőcse, Selmecbánya, Český Krumlov, Esztergom, Zakopáne) (Matlovič 2004).

A szocialista város belsỏ szerkezetének vizsgálata lehetővé teszi a jellegzetes vonások nagy számának elhatárolását (1. ábra). A szocialista város belső társadalmi (népesedési) térszerkezete jellegzetesen homogén, a szegregáció, az elkülönülés kis mértékủ. Ennek ellenére a területi elrendeződésben voltak egyenlőtlenségek. A társadalmi egyenlötlenséget az anyagi javak ujraelosztásán és a lakások elosztásán keresztül megszüntették. A szocialista városok lakosainak társadalmi-gazdasági státuszában meglévő különbség volt az a jelenség, amely kifejezte, hogy a lakosok megoszlása nagyon kevert. Másrészt a népességen belüli különbségek a család státusza szerint lényegbevágó fontosságúak voltak. A kelet-európai szocialista városok népességének térszerkezete a társadalmi státusz mértéke szerint csökken a városközponttól kifelé, vagyis sávos szerkezet tapasztalható.

\section{1. ÁBRA}

Állami beruházások zónánként a szocialista városokban

(National Investments in the Individual Urban Zones in the Socialist City)

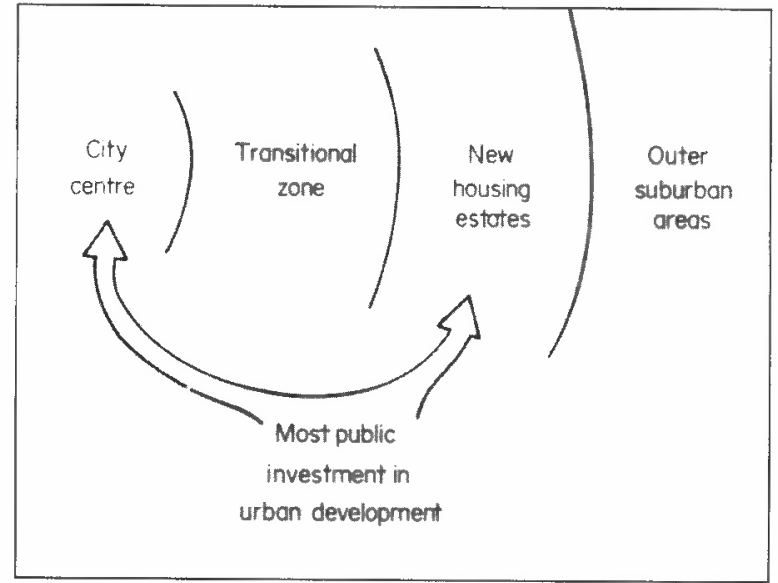

Képmagyarázat: City centre - városközpont; Transitional zone - átmeneti zóna; New housing estates - új lakótelepek; Outer suburban areas - kertváros. Most public investment in urban development - A városfejlödés legnagyobb beruházásai. Forrás: Sýkora (2001). 
Janetta Dická : A városi népesség térszerkezete Európa poszt-szocialista régiójában.

Tér és Társadalom 21. évf. 2007/3. 187-195. p.

TÉT XXI. évf. 2007 घ 3

Kitekintö

191

2. ÁBRA

A kelet-európai szocialista városok növekedési modellje (The Growth Model of the East European Socialist City)

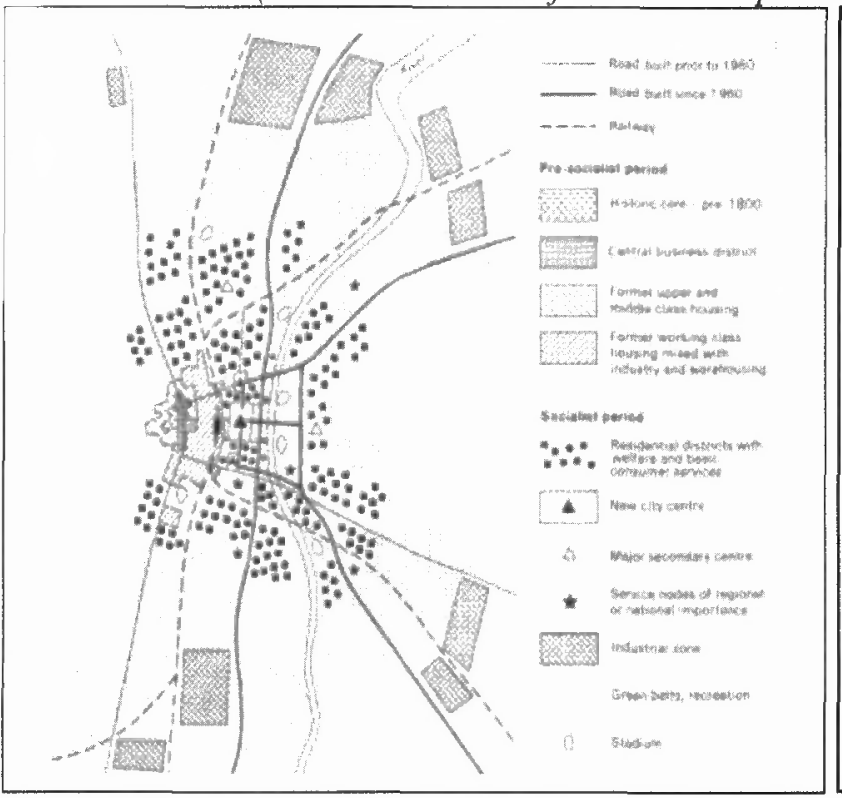

Képmagyarázat:

1960 elött épült utak

1960 óta épült utak

Vasút

A szocializmus elötti

korszak

Történelmi városmag 1800

elött

Központi ủzleti negyed

A hajdani felsö- és közép-

osztály lakóövezete

A hajdani munkásosztály

lakóővezete, keveredve az

ipari épületekkel és raktá-

rakkal

Szocialista korszak

Lakóövezet jóléti és

alapellátáshoz tartozó

szolgáltatásokkal

Új városközpont

Másodkőzpont

Szolgáltató központ regionális vagy országos jelentőséggel

Ipari zóna

Zoldövezet

Sportterek

Forrás: French-Hamilton 1979 - idézi Rouppila (2004).

\section{3. ÁBRA}

A társadalmi státusz különbözösége a belvárostól való távolság függvényében (Differentiation of the Social Status on Dependence from the Distance of the Downtown)

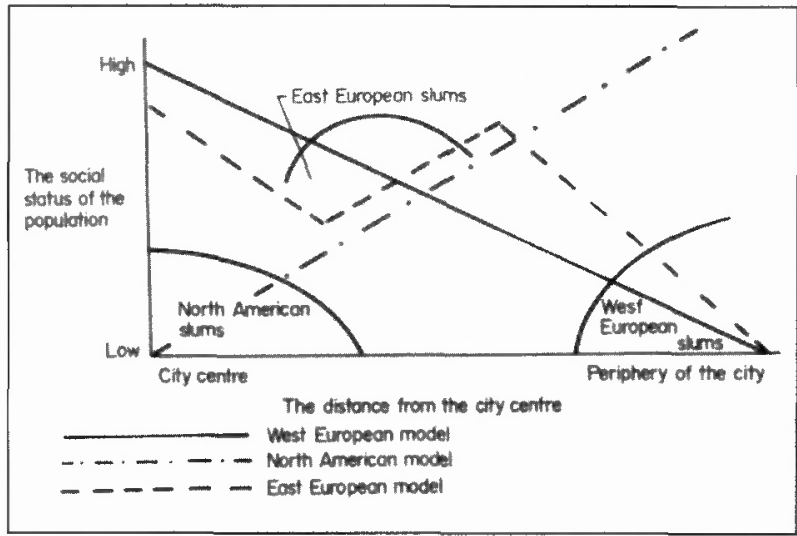

Függöleges tengely: a népesség társadalmi státusza (magas-alacsony).

Vízszintes tengely: távolság a városközponttól (városközpont - városszél).

Forrás: Sýkora (2001). 


\section{Poszt-szocialista város}

A poszt-szocialista városok az átmeneti és ideiglenes változatát mutatják annak a fejlődési formának, amelyet a szocialista rendszer összeomlása és az azt követő politikai-társadalmi-gazdasági átalakulás befolyásolt a kapitalista város felé vezető fejlődés útján. Ez pedig a város térszerkezetének alkalmazkodása az új feltételekhez. A fö változások azokat a városrészeket érintik, amelyek a funkcionalitás, az építészeti forma vagy a népesség társadalmi összetétele értelmében nem felelnek meg az új feltételeknek (Sýkora 2001; Matlovič 2004). A „poszt” előtag jelzi az új társadalmi forma elkülönülését a korábbitól, azaz a szocialistától, a kommunistától.

Földrajzi értelemben kulcsfontosságú a városok belső térszerkezetének változása. Ennek következtében a poszt-szocialista városok tanulmányozásának azt kell megcéloznia, hogy a városok fizikai, funkcionális és társadalmi karakterében hol és milyen jellegzetes változások következnek be. Ahogyan Sýkora (2001) állítja, a poszt-szocialista városok térbeli szerkezetük változásain keresztül jellemezhetök. Eszerint a poszt-szocialista városok modelljének megalkotásában a térbeli szerkezetük változásának megértése jelenti a segítséget, figyelve a változások okaira.

A városok területi szerkezetében bekövetkezett új folyamatok és az ebböl következő változások oka a poszt-szocialista városok új társadalmi körülménye, amelyek az 1990-es években kezdődtek. Enyedi (1998) a városi körülmények megváltozását eredményező fő́ tényezők közé sorolja a településrendszer piaci irányú változásait, a városok gazdaságának, társadalmának és épített környezetének átalakulását. Musil $(2000 ; 2003)$ és Sýkora (2001) a következőképpen magyarázzák az átalakulás folyamatát:

a) a központi-bürokratikus gazdasági mechanizmus átváltozása piacgazdaságira,

b) a magántulajdon elsőbbségének helyreállítása és a földbérlet újraindítása,

c) a városok igazgatásának többpárt-rendszerü alapokra helyezése,

d) az egység és a sokféleség értékének visszatérése a politika és az eszmei küzdelmek világába.

A városok térbeli szerkezetének változása visszahatás gazdasági-társadalmipolitikai változásokra, bizonyos időbeli eltolódással, amely az épített szerkezetek tartóssága miatt természetes. A város térszerkezetének, fóleg morfológiai és funkcionális tulajdonságainak átalakulását ennél fogva úgy lehet tekinteni, mint a társadalmi rendszer változásának megerősítését (Matlovič 2004).

Összefoglalva, a poszt-szocialista város, mint átmeneti város írható le, melynek különlegessége a két változás időtartamának különbségéből adódik. Az átalakulás első szakasza gyorsan változó területi mintákat hoz létre. A második szakaszban ez összefonódik magának a városnak a térszerkezetével (Sýkora 2001). Ennek megfelelően megállapítható, hogy a poszt-szocialista város átmeneti képződmény és ennek időtartama a város belső szerkezetének átalakulásától függ. 
Janetta Dická : A városi népesség térszerkezete Európa poszt-szocialista régiójában.

Tér és Társadalom 21. évf. 2007/3. 187-195. p.

TÉT XXI. évf. 2007 घ 3

Kitekintö

193

\section{Az átalakulás folyamatának és változásainak osztályozása a városok népességszerkezetében}

Csak nagy nehézségek árán lehet elkülöniteni a városok belső szerkezetében végbement változások közül azokat, amelyek a szocialista város kapitalista várossá változásakor, illetve a globalizáció folyamatában történtek. Matlovič (2004) szerint a városi térszerkezet változásainak vizsgálatához elengedhetetlen az egyes változási hatások tanulmányozása, úgymint a formai, a funkcionális és a népesedési. A meglévő szerkezeti részek és azok változása kölcsönhatásban vannak egymással, annak ellenére, hogy időben eltéró módon változtak. A leggyorsabban a társadalminépesedési térszerkezet változik, másrészt a legellenállóbbak a változásokkal szemben a morfológiai változások, miközben a társadalmi-népesedési térszerkezet változásának következésképpen válaszolni kell a morfológiai és funkcionális változásokra. A megállapított tényekből származik az igény a városok térszerkezetében lezajló változások folyamatának osztályozására.

Többek között Sýkora (2001) és Matlovič (2001; 2004) munkáiban találhatunk táblázatos formában kísérletet a poszt-szocialista városok térszerkezetében végbemenő változások osztályozására. Az osztályozás legfőbb ösztönzője az az igény volt, hogy a poszt-szocialista városok térszerkezetében történt változásokat értékeljék. Sýkora (2001) szerint a következỏ szempontok szerint lehet elemzést folytatni: 1) városrészenkénti elemzés morfológiai, funkcionális és társadalmi-népességi szempontok alapján két vagy több időszakban; 2) a változásokhoz vezető folyamatok kiemelése a város térszerkezetében (pl. elüzletiesítés, középosztályosodás, külvárosiasodás); 3) a városi területek elkülönülése a változás karakterének és mélységének alapján (pl. városközpont, belváros, lakótelepek, villanegyed, városkörnyéki zóna). Az értékelö elemzés nem fejeződhet be a területi szerkezet és annak változásának puszta leírásával, hanem egyúttal értelmezni is kell az egyes változások eredetét.

A poszt-szocialista városok térszerkezetének átalakulásával foglalkozó munkák alaposan feltárták az egyes átalakulási eseményeket. Ennek ellenére Sýkora (2001) rámutat, hogy a városi térszerkezeti változások értékelése tekintetében a változásoknak nincs módszeres osztályozása. Az egyes változási folyamatok meghatározásában lényeges különbségek vannak attól függỏen, hogy mi a kutatás tárgya, és annak mi az ismeretelméleti és módszertani iránya. A megállapított tények lényeges meghatározásbeli eltérésekhez és számtalan vitához vezetnek. Matlovič (2001; 2004), aki áttekintette az átmenet folyamatát és annak hatását a poszt-szocialista városszerkezetre, bemutatja az általa meghatározott alapfogalmakat, a megfigyelt folyamatok leírását, azok egymáshoz való kölcsönös viszonyát, viszonyukat a városrészek szerkezetéhez, valamint az egyes városi területekhez (2. táblázat). 
Janetta Dická : A városi népesség térszerkezete Európa poszt-szocialista régiójában.

Tér és Társadalom 21. évf. 2007/3. 187-195. $p$.

194 Kitekintö

TÉT XXI. évf. 2007 — 3

\section{TÁBLÁZAT}

Az átmenet folyamatai és azok hatása a városok belső szerkezetére

(The Processes of the Transformation and Their Projection into Intraurban Structures and Zones of the Cities)

\begin{tabular}{|c|c|c|c|}
\hline $\begin{array}{c}\text { A város } \\
\text { belsö } \\
\text { szerkezete }\end{array}$ & Formai jegyek & Funkcionális jegyek & $\begin{array}{c}\text { Társadalmi- } \\
\text { népesedési sajátos- } \\
\text { ságok }\end{array}$ \\
\hline \multirow{6}{*}{ 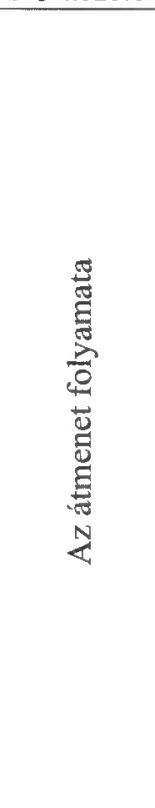 } & $\begin{array}{l}\text { Külvárosiasodás } \\
\text { (szuburbanizáció) - } \\
\text { E }\end{array}$ & $\begin{array}{l}\text { Külvárosiasodás } \\
\text { (szuburbanizáció) - E }\end{array}$ & $\begin{array}{l}\text { Külvárosiasodás } \\
\text { (szuburbanizáció) - } \\
\text { E }\end{array}$ \\
\hline & $\begin{array}{l}\text { Középosztályosodás } \\
\text { (dzsentrifikáció) - } \\
\text { B, A }\end{array}$ & $\begin{array}{l}\text { Elüzletiesedés } \\
\text { (kommercializálódás) } \\
\text { - A, E, B, D, C }\end{array}$ & $\begin{array}{l}\text { Középosztályosodás } \\
\text { (dzsentrifikáció) - } \\
\text { B, A }\end{array}$ \\
\hline & $\begin{array}{l}\text { Helyreállítás } \\
\text { (revitalizáció) - } \\
\text { A, B, C, D, E }\end{array}$ & $\begin{array}{l}\text { Az ipar visszahúzó- } \\
\text { dása } \\
\text { (deindusztrializáció) } \\
-\mathrm{B}\end{array}$ & $\begin{array}{l}\text { Elkülönítés (szegre- } \\
\text { gáció) - B, D, E }\end{array}$ \\
\hline & $\begin{array}{l}\text { Pangás (recesszió) - } \\
B, D, E\end{array}$ & $\begin{array}{l}\text { Lefegyverkezés (de- } \\
\text { militarizáció) - B }\end{array}$ & $\begin{array}{l}\text { Elszigetelödés } \\
\text { (izoláció) - A, B, E }\end{array}$ \\
\hline & & $\begin{array}{l}\text { A hitélet megerósö- } \\
\text { dése (szakralizáció) - } \\
\text { A, B, C, D, E }\end{array}$ & Státuszhanyatlás - D \\
\hline & & $\begin{array}{l}\text { A feladatok szakoso- } \\
\text { dása-A, B, E }\end{array}$ & \\
\hline
\end{tabular}

Zónák: A - városközpont, $\mathrm{B}$ - belváros, C - lakóövezet, D - lakótelep, E - külváros

Forrás: Matlovič (2004).Összegzés

Mind a szocialista, mind a poszt-szocialista korszakban vizsgálták a városi területek társadalmi-népesedési különbözőségét a fejlódés szempontjából. A szocialista város területi szerkezetét az iparositás és a modernizációs folyamatok útján formálták, ezen folyamatokon belül központi táradalomtervezéssel. A poszt-szocialista város egy átmeneti és időleges formája a fejlődésnek, amelyet a szocialista rendszer összeomlása és az azt követő társadalmi átalakulás befolyásolt, amely a kapitalista város kialakulása irányába mutatott. A városszerkezet az új feltételekhez alkalmazkodott.

A poszt-szocialista országokban a városi átmenet vizsgálata a városföldrajz kutatási területéhez tartozik. A társadalmi-népesedési változások a városszerkezetben mélyebbek voltak a fóvárosokban és a nagyvárosokban (pl. Kassán is). A poszt-szocialista országok más városaival együtt, mint amilyen Brno és Miskolc, jelentik az adott téma következö közös kutatási területét. Ezek a kiválasztott városok az illető országok perifériális területeinek nagyvárosai (a fóvárosok helyzetéhez képest), és hasonló helyzetben vannak az adott ország településhálózatában (második-harmadik legna- 
gyobb városok). Felállitható az a hipotézis, hogy a fövárosokkal való összehasonlításuk felhívhatja a figyelmet az egyes országok kiválasztott városaiban az egyedi folyamatok időbeli eltolódására, föleg a külvárosiasodás, a középosztályosodás és a státusz-hanyatlás folyamatában.

\section{Jegyzet}

${ }^{1}$ A tanulmány a VEGA č.1/2004/05. keretében készült: A fejlödés sajảtos vonásai és a területi különbségek Kassa régióban társadalomföldrajzi szempontból.

\section{Irodalom}

Carter, H. (1995) Social areas of the city and social characteristics of residential areas. - Carter, H. The study of urban geography. Fourth edition, Arnold, London. 221-233. o.

Dická, J. (2006) Vplyv transformačného procesu na rozmiestnenie abyvatelstva mesta Košice v rakach 1991 a 2001 . ACTA FSHNUP, Prírodné vedy XLIV, Folia geographica 9, FHPV PU Prešov, 8s. - v tlači.

Enyedi, Gy. (1998) Transformation in Central European Postsocialist Cities. - Enyedi, Gy. (ed.) Social Change and Urban Restructuring in Central Europe. Akademiai Kiadó, Budapest. 9-35. o.

Gajdoš, P. (2002) Človek, Spoločnost, Prostredie - Priestorová sociológia. Sociologický ústav SAV, Bratislava.

Kempen, E.T. (1994) The dual city and the poor: social polarisation, social segregation and life changes. - Urban Studies. Vol. 31. 995-1015. o.

Kempen, R. -Ozuekren S.A. (1998) Ethnic segregation in cities: New forms and explanations in a dynamic world. - Urban Studies. Vol. 35. Iss 10.

Kulla, M. (2005) Priemysel Košíc - minulost', súčasnost' a budúcnost'. Geografické aspekty středoevropského prostoru, Sborník př́spěvku z 13. mezinárodní konference, GEOGRAFIE XVI, Masarykova universita, Brně. 289-296. o.

Matlovič, R. (2001) Transformačné procesy a ich efekty $\mathrm{v}$ intraurbánnych štruktúrach postkomunistických miest. - Baran, V. (ed.) Premeny Slovenska v regionálnom a didaktickom kontexte. Acta Facultatis Rerum Naturalium Universitatis Matthiae Belii, Geografické štúdie. 8. UMB Banská Bystrica, 73-81. o.

Matlovič, R. (2004) Tranzitívna podoba mesta a jeho intraurbảnnych štruktúr v ére postkomunistickej transformácie a globalizácie. - Sociológia. 2. 137-158. o.

Musil, J. (2000) Vývoj a plánování měst ve střední Evropě v období komunistických režimů. Sociologický časopis. 3. 275-296. o.

Musil, J. (2003) Proměny urbánní sociologie ve Spojených státech a Evropě 1950-2000. - Sociologický časopis. 2. 137-167. o.

Ruoppila, S. (2004) Processes of Residential Differentiation in Socialist Cities. Literature review on the cases of Budapest, Prague, Tallinn and Warsaw. - European Journal of Spatial Development. http://www.nordregio.se/EJSD, Refereed Articles, 9. o.

Sýkora, L. (1993) Gentrifikace: měnící se tvář vnitřních mèst. - Teoretické př́stupy a vybrané problémy v současné geografii. PF KU, Praha. 100-119. o.

Sýkora, L. (2001) Post-communist city. - XII Konwersatorium Wiedzy o Mieście. Miasto postsocjalistyczne - organizacja przestrzeni miejskiej i jej przemiany, Lódź, Katedra Geografii Miast i Turyzmu Universytetu Łódzkiego, Komisja Geografii Osadnictwa i Ludności PTG, Lódzkie Towarzystwo Naukowe. 41-45. o.

Sýkora, L-Temelová, J. (2005) Prevence prostorové segregace. Univerzita Karlová v Praze, Př́r. fakulta, Ministerstvo pro místni rozvoj, Praha. www.mmr.cz

Węcławowicz, G. (1988) Social polarisation in postsocialist cities: Budapest, Prague, Warsaw. - Enyedi, Gy. (ed.) Social Change and Urban Restructuring in Central Europe. Akadémiai Kiadó, Budapest. 55-56, o. 